MRS Advances (C) 2017 Materials Research Society

DOI: $10.1557 /$ adv.2017.449

\title{
Atmospherically Processed and Stable Cs-Pb Based Perovskite Solar Cells
}

\author{
Shubhra Bansal, Michelle Chiu \\ Department of Mechanical Engineering, Center of Energy Research, University of Nevada Las \\ Vegas, Las Vegas, Nevada 89154, U.S.A.
}

\begin{abstract}
In this work, a planar heterojunction superstrate n-i-p device based on $\mathrm{Zn}(\mathrm{O}, \mathrm{S})$ electron transport layer and $\mathrm{CsPbI}_{2} \mathrm{Br}$ absorber material at $1.93 \mathrm{eV}$ bandgap is presented. The $\mathrm{CsPbI}_{2} \mathrm{Br}$ films are deposited using a 2-step atmospheric solution deposition process and characterized by X-ray diffraction (XRD), scanning electron microscopy (SEM), UV-vis spectroscopy and photoluminescence (PL). Best device with an efficiency of $12.34 \%$ and $11.94 \%$ in reverse and forward scans respectively and stabilized power output of $12.14 \mathrm{~mW} / \mathrm{cm}^{2}$ has been demonstrated via atmospheric solution processing with minimal hysteresis between forward and reverse scans. The devices show voltage dependent current collection as well as light-dark crossover in forward bias. Light soaking tests at $65{ }^{\circ} \mathrm{C}$ and 1 -sun at $\mathrm{V}_{\text {oc }}$, resulted in open-circuit voltage and fill-factor degradation. Electroluminescence (EL) after 100 hours of light soaking shows a reduction in overall EL intensity as well a shift in emission to lower wavelength. The devices exhibit a positive temperature coefficient of about $0.14 \% /{ }^{\circ} \mathrm{C}$. It is found that $\mathrm{Zn}(\mathrm{O}, \mathrm{S})$ is a viable alternative electron transport layer to replace $\mathrm{TiO}_{2}$. By replacing methylammonium cation with cesium and addition of $\mathrm{Br}$ has improved the stability of the perovskite phase.
\end{abstract}

\section{INTRODUCTION}

Since the introduction of methylammonium lead halide based solar cells by Kojima et al. in 2009 [1], organic-inorganic hybrid perovskites have gained significant attention as an absorber layer in thin film solar cells. The characteristics exhibited by these materials such as high absorption coefficient [2], excellent transport properties [3], tunable bandgap [4], absence of deep trap states within the bandgap [5-6], low temperature processing etc. [7-9], make the materials suitable for low cost photovoltaic applications. Consequently, the photo-conversion efficiency of devices based on these materials has improved dramatically from $3.8 \%$ to $22.1 \%$ in a relatively short span of time [10-11]. Despite several advantages of perovskites, the application of these materials in commercial PV modules is seriously hindered by their stability. Perovskites have been shown to degrade rapidly upon exposure to heat, moisture, air, and light [4,8,12-14]. Limited success has been achieved in improving device stability by encapsulating devices $[15,16]$. The formation energy of $\mathrm{MAPbX}_{3}$ has been reported to be very low, which makes these materials unstable at high temperatures and in humidity [17]. By replacing the organic cation with inorganic $\mathrm{Cs}$, the intrinsic material stability can be improved [18]. Mixed A-cation [19-21] and mixed-halide systems have shown to be more structurally stable than $\mathrm{MAPbI}_{3}$ due to increased formation energy and tolerance factors [22].

Conventionally used ETL and HTL materials are not completely immune to degradation either. $\mathrm{TiO}_{2}$, which is a commonly used ETL material, has been known to be susceptible to UV induced degradation since late 1970s [23]. Upon exposure to UV radiation, oxygen desorption occurs creating oxygen vacancies $\left(\mathrm{Ti}^{3+}\right.$ sites) on the surface of $\mathrm{TiO}_{2}$ [24]. The surface energy levels resulting from changes in the electronic structure are found to be in the mid-gap region of the bulk 
material. When perovskite absorber material gets photo-excited, electrons are injected into the conduction band of $\mathrm{TiO}_{2}$, where they become trapped into the mid-gap surface traps and readily recombine with holes. Leijtens et al. have reported performance degradation of $\mathrm{TiO}_{2}$ based devices upon exposure to UV radiation [16, 25]. Improved device stability was observed using a UV filter and by replacing $\mathrm{TiO}_{2}$ with $\mathrm{Al}_{2} \mathrm{O}_{3}$ [16]. Furthermore, the increased defect density at $\mathrm{TiO}_{2} /$ perovskite interface has been shown to be associated with increased hysteresis effect in devices, as well [26]. Even though the degradation can be reduced using a UV filter, it is only achieved at a cost of photocurrent as well as complexity in device fabrication [16]. Both P3HT and Spiro-OMeTAD HTLs are also prone to degradation [13]. In the case of P3HT, the decrease in device performance is attributed to the photo-chemical degradation of the material [13] driven by $\mathrm{UV}$, humidity and temperature. On the other hand, the decrease in $\mathrm{V}_{\mathrm{OC}}$ and $\mathrm{J}_{\mathrm{SC}}$ in the case of SpiroOMeTAD observed by Matteocci et al. was attributed to changes in the oxidation state of SpiroOMeTAD resulting in partial de-doping of the material [13]. Recently, attempts have been made to substitute the organic hole transport layers with $\mathrm{CuSCN}$ [27], $\mathrm{NiO}_{\mathrm{x}}[28,29], \mathrm{CuI}$ [30], etc. and the electron transport layer $\mathrm{TiO}_{2}$ with $\mathrm{ZnO}[29,31]$. You et al. [29] have reported a solar cell with $\mathrm{ZnO}$ as the ETL and $\mathrm{NiO}_{\mathrm{x}}$ as the HTL with an efficiency of $16.1 \%$ and a significant improvement in device stability. Similarly, Huang et al. [32] have replaced $\mathrm{TiO}_{2}$ with $\mathrm{CdS}$, which significantly improved device stability, as compared to the case of $\mathrm{TiO}_{2}$, over a $12-\mathrm{hr}$ period.

\section{EXPERIMENT}

Superstrate n-i-p devices were fabricated using a modified 2-step process [33]. Glass with $\mathrm{F}: \mathrm{SnO}_{2}$ transparent conducting oxide (TCO) was first cleaned in an ultrasonic bath and $50 \mathrm{~nm}$ thick $\mathrm{Zn}(\mathrm{O}, \mathrm{S})$ was deposited via chemical bath deposition using a $\mathrm{Zn}$-sulfate chemistry [34]. $\mathrm{Zn}(\mathrm{O}, \mathrm{S})$ was deposited in a bath of zinc-sulfate, thiourea and ammonium hydroxide at $80^{\circ} \mathrm{C}$ while stirring at $500 \mathrm{rpm}$. The substrates were then cleaned with $2.5 \%$ ammonium hydroxide solution and water followed by air drying. The sunny side of glass was cleaned with dilute $\mathrm{HCl}$ to remove $\mathrm{Zn}(\mathrm{O}, \mathrm{S}) . \mathrm{Zn}(\mathrm{O}, \mathrm{S})$ substrates were then pre-heated at $70{ }^{\circ} \mathrm{C}$ and partial electrolyte treatment was done using a $0.5 \mathrm{M} \mathrm{PbCl}_{2}$ solution in methanol. The $\mathrm{PbCl}_{2}$ treatment is expected to improve the doping density of the $\mathrm{Zn}(\mathrm{O}, \mathrm{S})$ and help with nucleation of the perovskite film [33, 35]. A $0.5 \mathrm{M}$ precursor of $\mathrm{CsI}, \mathrm{PbI}_{2}, \mathrm{CsBr}, \mathrm{PbBr}_{2}$ in $\mathrm{N}, \mathrm{N}$-Dimethylformamide (DMF) was prepared in dry air conditions at $70{ }^{\circ} \mathrm{C}$ with 4 hours stir time. The intended $\mathrm{I} /(\mathrm{I}+\mathrm{Br})$ ratios in the precursor was 0.67 . $100 \mu \mathrm{L}$ of solution was then spin-coated on the 1" x 1" substrates at $2000 \mathrm{rpm}$ for 45 seconds. 100 $\mu \mathrm{L}$ of chlorobenzene applied at 25 seconds to improve the morphology of the films [19]. To get uniform film thickness and to incorporate enough $\mathrm{Br}$ in the films, a spray treatment of $\mathrm{CsBr}$ and $\mathrm{PbBr}_{2}$ solution in methanol was done at the end of spin coating cycle. The films were then annealed at $350{ }^{\circ} \mathrm{C}$ for 10 minutes in dry air conditions. It is noted that without the $\mathrm{CsBr}$ and $\mathrm{PbBr}_{2}$ treatments, we obtained the dark brown-black $\mathrm{CsPbI}_{3}$ phase at $350{ }^{\circ} \mathrm{C}$ which quickly turned into the yellow phase when cooled to room temperature. It has been observed that $\mathrm{CsPbI}_{3}$ is stable in non-perovskite orthorhombic (yellow) phase at room temperature and changes to the cubic perovskite (black) phase when heated above $300^{\circ} \mathrm{C}[36,37]$. A carbon paste Acheson Electrodag 456C in MEK was then spin coated to form the hole transport layer followed by thermal evaporation of $\mathrm{Au}$. The front contact was formed by indium paste applied directly to the TCO by lightly scratching the $\mathrm{Zn}(\mathrm{O}, \mathrm{S})$ layer. X-ray diffraction on films was done using PANalytical X'PERT Pro X-ray Diffraction Spectrometer. UV-Vis measurements were conducted using a Shimadzu UV-2600 plus spectrophotometer. Photoluminescence measurements were performed 
using a $488 \mathrm{~nm}$ Argon/Krypton Stabilite 2018 ion laser at $100 \mathrm{~mW} / \mathrm{cm}^{2}$. Solar cell J-V characteristics were measured using ATLAS XXL+ solar simulator calibrated using a standard cSi cell. Quantum efficiency measurements were made using PV Measurements Inc. QEXL system. All solar cells and perovskite thin films were subjected to light soaking at 1 -sun and $65^{\circ} \mathrm{C}$ using an ATLAS XXL+ light soak chamber with Xenon-arc lamps. SCAPS-1D [38] device model for $\mathrm{CH}_{3} \mathrm{NH}_{3} \mathrm{PbI}_{3}$ solar cells validates the treatment as superstrate $\mathrm{n}-\mathrm{i}-\mathrm{p}$ devices as explained elsewhere [39].

\section{RESULTS AND DISCUSSION}

Figure 1a shows the absorption and photoluminescence (PL) spectra of $\mathrm{CsPbI}_{2} \mathrm{Br}$ films. The absorption peak is observed at about $640 \mathrm{~nm}$ corresponding to a bandgap of $1.93 \mathrm{eV}$ and PL shows variation in peak position between $625 \mathrm{~nm}$ to $640 \mathrm{~nm}$, indicating presence of micro nonuniformities. For $\mathrm{x}=0.67$, the measured XRD spectrum (Figure $1 \mathrm{~b}$ ) agrees well with literature data for $\mathrm{CsPb}_{2} \mathrm{Br}$ for the (100) and (200) peak positions and a preferred orientation in (100) direction $[35,40]$. The peak positions are shifted to high $2 \theta$ as compared to cubic $\mathrm{CsPbI}_{3}$ due to lattice contraction resulting from $\mathrm{Br}$ substitution of I. As previously observed (110) and (111) peaks are negligible intensity for $\mathrm{CsPb}_{2} \mathrm{Br}$ perovskite phase. To check the stability of the films under solar cell operating conditions, thin films were subjected to 1 -sun and $65{ }^{\circ} \mathrm{C}$ anneal conditions. XRD pattern for as deposited, after 50 and 100 hours anneal are shown in Figure $1 \mathrm{~b}$. XRD data shows onset of peak at $20^{\circ}$ indicating formation of $\mathrm{CsPbI}_{3}$ after 100 hours of light soaking, resulting from halide segregation or non-uniformities. Hoke et al. [41] have reported segregation of iodine rich domains with lower bandgap and increased sub-bandgap absorption leading to red shift in $\mathrm{PL}$. $\mathrm{CsPbI}_{2} \mathrm{Br}$ has been shown to be stable at temperatures more than $85^{\circ} \mathrm{C}$ [35], therefore, we believe the perovskite phase is intrinsically stable and further process and crystal control is needed to obtain long-term stability. Results from six devices are summarized in Table 1 including the best device at $12.34 \%$ power conversion efficiency and a stabilized power output (SPO) of $12.14 \mathrm{~mW} / \mathrm{cm}^{2}$. The SPO was measured by holding the device at $1.1 \mathrm{~V}$ under standard test conditions (STC). We could obtain a tight distribution in device efficiency indicating the robustness of the process. All devices were measured in ambient conditions $(<25 \% \mathrm{RH})$ without encapsulation.
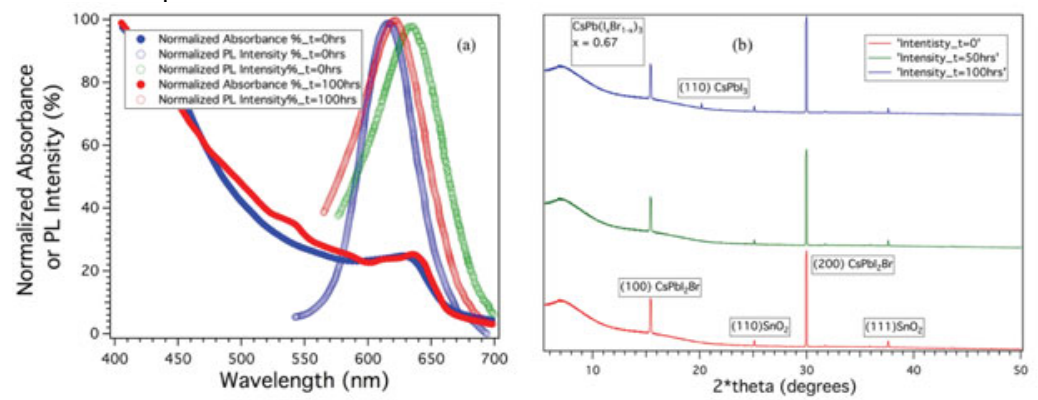

Figure 1. (a) Normalized absorbance and $\mathrm{PL}$ data for $\mathrm{CsPb}_{2} \mathrm{Br}$ films at 0 and 100 hours. PL measurements at 0 hours indicate regions of micro-nonuniformities in composition. (b) XRD scans on $\mathrm{CsPbI}_{2} \mathrm{Br}$ after 0 , 50 and 100 hours anneal at 1 -sun and $65^{\circ} \mathrm{C}$. 

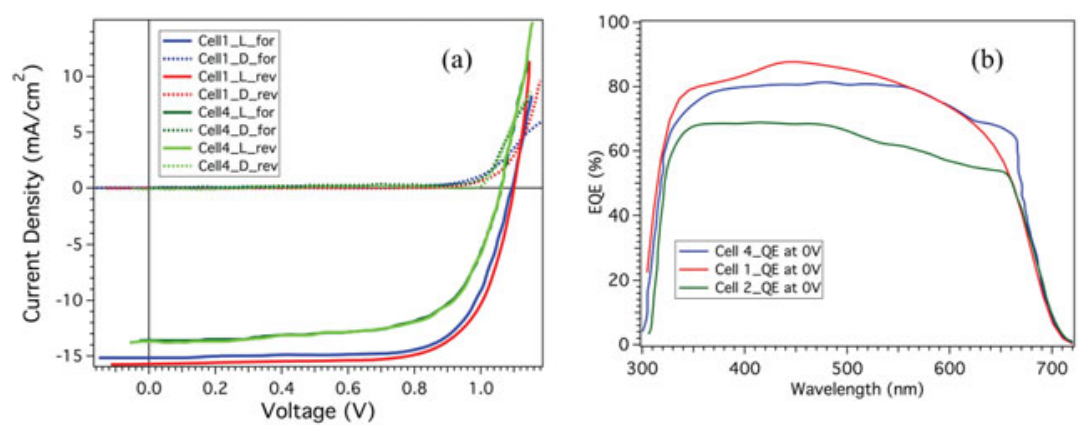

Figure 2. (a) $\mathrm{J}-\mathrm{V}$ scans in forward and reverse bias for $5 \mathrm{~mm}$ x $5 \mathrm{~mm} \mathrm{CsPbI}_{2} \mathrm{Br}$ devices. Both cells indicate voltage dependent current collection in light curves and light-dark crossover in forward bias. (b) Experimental quantum efficiency for $\mathrm{CsPbI}_{2} \mathrm{Br}$ devices indicates losses in longer wavelength region likely due to incomplete carrier collection that may be attributed to non-uniform perovskite thickness.

Table 1. Cell parameters for six $\mathrm{Zn}(\mathrm{O}, \mathrm{S}) / \mathrm{CsPbI}_{2} \mathrm{Br}$ devices

\begin{tabular}{|c|c|c|c|c|c|c|c|c|c|}
\hline $\begin{array}{c}\text { Cell } \\
\#\end{array}$ & $\begin{array}{l}V_{\text {oc }} \\
\text { (V) }\end{array}$ & $\begin{array}{c}\mathbf{J}_{\mathrm{sc}} \\
\left(\mathrm{mA} / \mathbf{c m}^{2}\right)\end{array}$ & $\begin{array}{l}\text { FF } \\
(\%)\end{array}$ & $\begin{array}{l}\text { Eff } \\
(\%)\end{array}$ & $\begin{array}{c}\text { Stabilized } \\
P_{\max } \\
\left(\mathrm{mW} / \mathrm{cm}^{2}\right)\end{array}$ & $\underset{\left(\mathrm{mA} / \mathrm{cm}^{2}\right)}{\mathrm{QE} \mathbf{J}_{\mathrm{sc}}}$ & $\begin{array}{l}\text { est. Eff } \\
(\%) w / \\
Q E J_{s c}\end{array}$ & $\begin{array}{l}V_{\text {oc }} \text { at } \\
65^{\circ} \mathrm{C}\end{array}$ & $\begin{array}{c}\text { Estimated } \\
\text { Temperature } \\
\text { Coefficient } \\
\left(\% /{ }^{\circ} \mathrm{C}\right)\end{array}$ \\
\hline 1 & 1.1 & 15.7 & 71.43 & 12.33 & 12.14 & 14.38 & 11.3 & 1.165 & 0.15 \\
\hline 2 & 1.245 & 10.1 & 72.05 & 9.06 & 9.11 & 9.96 & 8.94 & 1.3 & 0.12 \\
\hline 3 & 1.07 & 13.22 & 68.4 & 9.66 & 9.54 & 12.68 & 9.28 & 1.123 & 0.12 \\
\hline 4 & 1.063 & 13.68 & 69.91 & 10.23 & 10.4 & 12.75 & 9.54 & 1.123 & 0.14 \\
\hline 5 & 1.09 & 14.85 & 70.02 & 11.3 & 11.33 & 14.52 & 11.08 & 1.15 & 0.14 \\
\hline 6 & 1.12 & 15.05 & 70.88 & 11.95 & 12.01 & 14.21 & 11.28 & 1.188 & 0.15 \\
\hline
\end{tabular}

As shown in Figure 2a, the best device had an efficiency of $12.34 \%$ in a reverse scan and $11.94 \%$ in forward scan with $\mathrm{V}_{\text {oc }}$ of $1.1 \mathrm{~V}$ and $1.094 \mathrm{~V}$ respectively. Light generated current $\left(\mathrm{J}_{\mathrm{L}}\right)$ during forward scan is $15.15 \mathrm{~mA} / \mathrm{cm}^{2}$ and $15.7 \mathrm{~mA} / \mathrm{cm}^{2}$ for the reverse scan. Further, we observed some voltage dependent collection in the light curves as well as light-dark crossover in forward bias. Due to the voltage dependent collection, $\mathrm{J}_{\mathrm{L}}$ is different from $\mathrm{J}_{\mathrm{sc}}$, which agrees well with the QE estimated $\mathrm{J}_{\mathrm{sc}}$. All values for the six devices are reported in Table 1. The best device was held at a constant bias of $1.1 \mathrm{~V}$ to yield a stabilized power output of $12.14 \mathrm{~mW} / \mathrm{cm}^{2}$, which is reasonable as minimal hysteresis is observed between forward and reverse scans. The efficiency reported here shows an improvement over two previous reports of $\mathrm{CsPbI}_{2} \mathrm{Br}$ devices $[35,40]$ which may be attributed to improved $\mathrm{J}_{\mathrm{sc}}$ and FF. Our devices use F: $\mathrm{SnO}_{2} / \mathrm{Zn}(\mathrm{O}, \mathrm{S})$ as well as a $\mathrm{PbCl}_{2}$ pre-treatment before perovskite deposition among key differences. The $\mathrm{V}_{\mathrm{oc}}$ deficit is high which is being addressed by tailoring of $\mathrm{Zn}(\mathrm{O}, \mathrm{S})$ /perovskite interface, thickness control of perovskite layer and a better HTL such as $\mathrm{NiO}$ or $\mathrm{CsSnI}_{3}$. As shown in the focused ion beam cross-section we see potential leakage paths which may lead to weak diodes and decrease in $\mathrm{V}_{\text {oc }}$ because of non-uniform deposition of $\mathrm{Zn}(\mathrm{O}, \mathrm{S})$. It can also be seen from FIB-SEM images that thickness and film quality of $\mathrm{CsPb}_{2} \mathrm{Br}$ needs further improvement (Figure $3 \mathrm{c}$ ). 

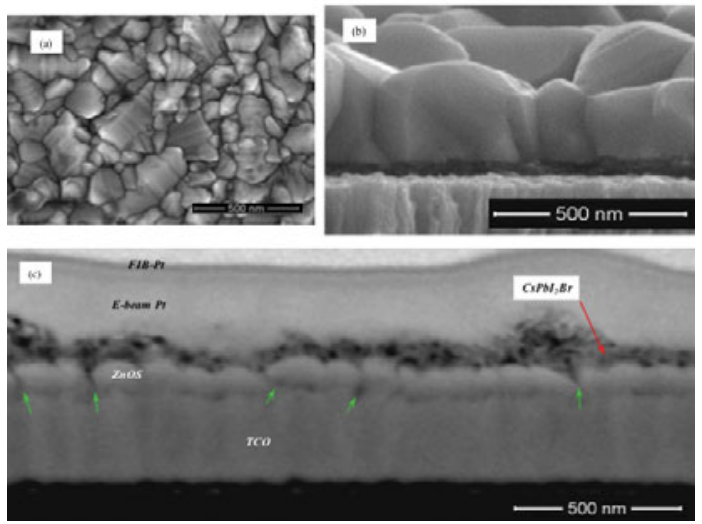

Figure 3. (a) Top-down $\mathrm{SEM}$ image for solution processed $\mathrm{CsPb}_{2} \mathrm{Br}$ film on $\mathrm{SnO}_{2}$ (b) Cross-sectional view of cleaved sample of $\mathrm{CsPbI}_{2} \mathrm{Br}$ film on $\mathrm{SnO}_{2}$ (c) FIB-SEM cross-sectional image of TCO/ $\mathrm{Zn}(\mathrm{O}, \mathrm{S}) /$ $\mathrm{CsPbI}_{2} \mathrm{Br}$ film stack. Perovskite layer appears not fully crystallized and $\mathrm{Zn}(\mathrm{O}, \mathrm{S})$ film shows pin-holes.

Three of the devices were subjected to light soak testing at 1 -sun $\left(1000 \mathrm{~W} / \mathrm{m}^{2}\right)$ and $65^{\circ} \mathrm{C}$ for 100 hours under ambient conditions and in-situ JV measurements were made at regular intervals. The $\mathrm{V}_{\mathrm{oc}}$ of the device measured at $65^{\circ} \mathrm{C}$ was higher than measured at $25{ }^{\circ} \mathrm{C}$ indicative of a positive temperature coefficient of these materials. It has been reported bandgap of perovskite materials increases with temperature [42]. The open circuit voltage at $65{ }^{\circ} \mathrm{C}$ and estimated temperature coefficients are listed in Table 1. Figure 4 shows degradation data of cell parameters when the devices were stressed at 1 -sun, $65^{\circ} \mathrm{C}$ and open-circuit voltage conditions. The devices show degradation in air due to development of shunts and significant decrease in $\mathrm{V}_{\text {oc }}$ and $\mathrm{FF}$.

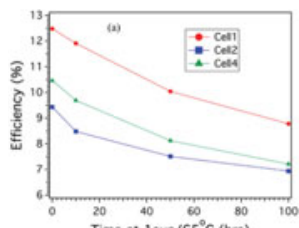

Time at 1 sun $/ 65^{\circ} \mathrm{C}$ (hrs)
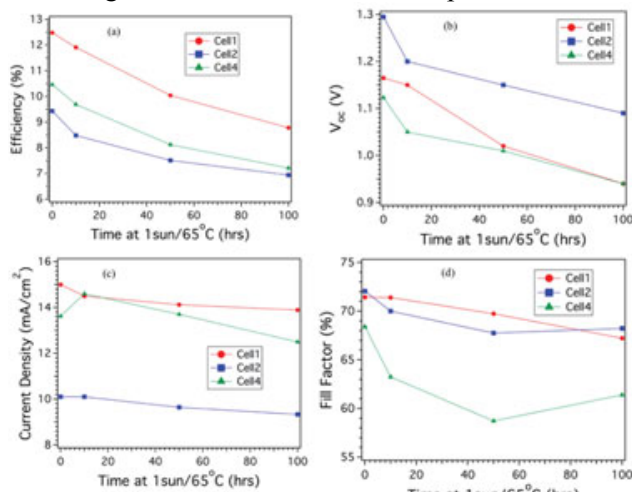

Time at 1 sun $/ 65^{\circ} \mathrm{C}(\mathrm{hrs})$

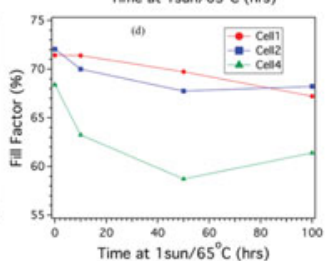

Figure 4. Degradation data of cell parameters (a) efficiency (b) opencircuit voltage (c) fill factor (d) current density for three devices stressed at 1 -sun, $65{ }^{\circ} \mathrm{C}$ and opencircuit voltage conditions.

The shunts formation may be due to disintegration of $\mathrm{CsPbI}_{2} \mathrm{Br}$ into $\mathrm{CsPbI}_{3}$ or $\mathrm{PbI}_{2}$ as indicated by Sutton et al. [43]. Another speculation is the probes used for J-V measurements may cause scratching and hot-spot formation. Electroluminescence (EL) images on Cell 4 before and 
after 100 hours at 1 -sun and $65{ }^{\circ} \mathrm{C}$ are shown in Figure 5. Images were taken at a current density of $60 \mathrm{~mA} / \mathrm{cm}^{2}$ equivalent to about 4 suns using a $0.5 \mathrm{x}$ objective. EL images indicate lower intensity consistent with appearance of shunts and lower $\mathrm{V}_{\text {oc }}$ with stress.

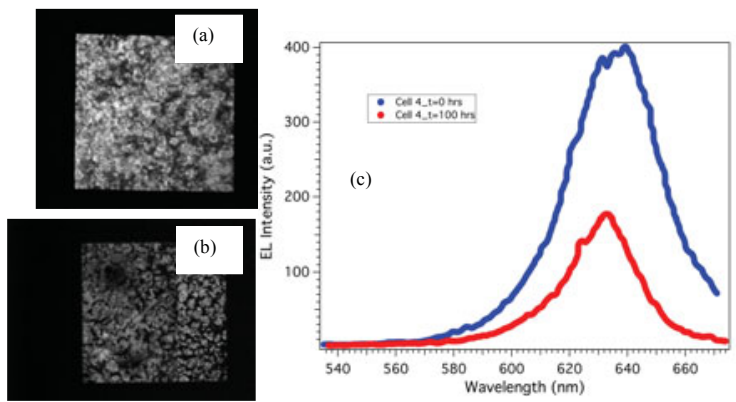

Figure 5.

Electroluminescence images of Cell 4 (a) before and (b) after light soak test. (c) Emission shifts from $640 \mathrm{~nm}$ to $633 \mathrm{~nm}$ after 100 hours of light soaking test.

\section{CONCLUSION}

Here we have demonstrated inorganic planar perovskite devices with power conversion efficiency of $12.34 \%$ and stabilized maximum power of $12.14 \mathrm{~mW} / \mathrm{cm}^{2}$, which represents highest performance reported yet for $\mathrm{CsPbI}_{2} \mathrm{Br}$ perovskite solar cells. These inorganic lead halide perovskites show a positive temperature coefficient, which needs further investigation. Positive temperature coefficient can possibly make these materials extremely attractive for high solar cell operating temperatures. The bandgap demonstrated here of $1.93 \mathrm{eV}$ is a great candidate for high efficiency tandem device structures with devices such as c-Si and CIGS [44, 45]. The structural stability, uniform deposition, microstructural control, micro non-uniformities are still open questions which need further fundamental understanding. We have also demonstrated $\mathrm{Zn}(\mathrm{O}, \mathrm{S})$ as an alternate electron transport material to address the stability issues of $\mathrm{TiO}_{2}$. Future research is needed to optimize the $\mathrm{Zn}(\mathrm{O}, \mathrm{S})$ process to obtain extremely uniform thin films for improved $\mathrm{V}_{\mathrm{oc}}$ and $\mathrm{J}_{\mathrm{sc}}$. Atomic layer deposition of $\mathrm{Zn}(\mathrm{O}, \mathrm{S})$ has been demonstrated at manufacturing scale by thin film manufacturers, making it a viable solution for substrate configuration needed for tandem device structures.

\section{REFERENCES}

1. A. Kojima, K. Teshima, Y. Shirai, T. Miyasaka, J. Am. Chem. Soc., 131, 17, 6050 (2009).

2. N.-G. Park, Mater. Today, 18, 65 (2015).

3. S. D. Stranks, G. E. Eperon, G. Grancini, C. Menelaou, M. J. Alcocer, T. Leijtens, L. M. Herz, A. Petrozza, H. J. Snaith, Science, 342, 6156, 341 (2013).

4. J. Noh, S. H. Im, J. H. Heo, T. N. Mandal, S. I. Seok, Nanoletters, 13, 1764 (2013).

5. W-J Yin, T. Shi, Y. Yan, Appl. Phys. Let., 104, 063903 (2014).

6. J. Kim, S. H. Lee, K. H. Hong, J. Phys. Chem. Lett., 5, 8, 1312 (2014).

7. W.S. Yang, J. H. Noh, N. J. Jeon, Y. C. Kim, S. Ryu, J. Seo, S. Seok, Science, 348, 1234 (2015).

8. J. Burschka, N. Pellet, S. J. Moon, R. H-Baker, P. Gao, M. K. Nazeeruddin, M. Grätzel, Nature, 499, 7458, 316 (2013). 
9. H. J. Snaith, J. Phys. Chem. Lett., 4, 21, 3623 (2013).

10. NREL efficiency chart http://www.nrel.gov/ncpv/images/efficiency chart.jpg (Accessed 23 April 2017).

11. M. Green, K. Emery, Y. Hishikawa, W. Warta, E. D. Dunlop, Prog. Photovol: Res. Appl.., 24, 1, 3 (2016).

12. T. Leijtens, G. E. Eperon, N. K. Noel, S. N. Habisreutinger, A. Petrozza, H. J. Snaith, $A d v$. Energy Mater., 5, 1500963 (2015).

13. F. Matteocci, S. Razza, F. D. Giacomo, S. Casaluci, G. Mincuzzi, T. M. Brown, A. D'Epifanio, S. Licoccia, A. D. Carlo, Phys. Chem. Chem. Phys., 16, 3918 (2014).

14. A. B. Djurisic, F. Liu, A. M. C. Ng, Q. Dong, M. K. Wong, A. Ng, C. Surya, Phys. Status Solidi RRL, 10, 4, 281, (2016).

15. Y. Han, S. Meyer, Y. Dkhissi, K. Weber, J. M Pringle, U. Bach, L. Spiccia, Y. B. Cheng, J. Mat. Chem. A, 3, 8139 (2015).

16. T. Leijtens, G. E. Eperon, S. Pathak, A. Abate, M. M. Lee, H. J. Snaith, Nat. Comm., 4, 3885 (2013).

17. D. B. Mitzi, Prog. Inorg. Chem., 48, 1 (2007).

18. A. Amat, E. Mosconi, E. Ronca, C. Quarti, P. Umari, M. K. Nazeeruddin, M. Grätzel, and F. De Angelis, Nano Lett., 14, 3608 (2014).

19. Z. Li, M. Yang, J-S. Park, S-H. Wei, J. J. Berry, K. Zhu, Chem. Mater., 28, 1, 284 (2016).

20. D. P. McMeekin, G. Sadoughi, W. Rehman, G. E. Eperon, M. Saliba, M. T. Hörantner, A. Haghighirad, N. Sakai, L. Korte, B. Rech, M. B. Johnston, L. M. Herz, H. J. Snaith, Science, 351, 6269, 151 (2016).

21. C. Yi, J. Luo, S. Meloni, A. Boziki, N. A-Astani, C. Grätzel, S. M. Zakeeruddin, U. Röthlisberger, M. Grätzel, Energy Environ. Sci., 9, 656 (2016).

22. W. Travis, E. N. K. Glover, H. Bronstein, D. O. Scanlon, R. G. Palgrave, Chem. Sci., 7, 4548 (2016).

23. G. Munura, V. Rives-Arna , and A. Saucedo , J. Chem. Soc., Faraday Trans. 1, 75, 736 (1979).

24. M.J. Llansola-Portoles, J.J. Bergkamp, D. Finkelstein-Shapiro, B. D. Sherman, G. Kodis, N. M. Dimitrijevic, D. Gust, T. A. Moore, and A. L. Moore, J. Phys. Chem. A, 118, 10631 (2014).

25. S.K. Pathak, A. Abate, T. Leijtens, D. J. Hollman, J. Teuscher, L. Pazos, P. Docampo, U. Steiner, H. J. Snaith, Adv. Energy Mater., 8, 1301667 (2014).

26. J.M. Azpiroz, E. Mosconi, J. Bisquertcd and F. D. Angelis, Energy Environ. Sci., 8, 2118 (2015).

27. P. Qin, S. Tanaka, S. Ito, N. Tetreault, K. Manabe, H. Nishino, M.K. Nazeeruddin and M. Grätzel, Nature Commun., 5, 3834 (2014).

28. Z. Zhu, Y. Bai, T. Zhang, Z. Liu, X. Long, Z. Wei, Z. Wang, L. Zhang, J. Wang, F. Yan, S. Yang, Angew. Chem. Int. Ed., 53, 12571 (2014).

29. J. You, L. Meng, T-B. Song, T-F. Guo, Y. Yang, W-H. Chang, Z. Hong, H. Chen, H. Zhou, Q. Chen, Y. Liu, N. D. Marco, Y. Yang, Nat. Nanotech., 11, 75 (2016).

30. J. A. Christians, R. C. M. Fung, P. V. Kamat, J. Am. Chem. Soc., 136, 2, 758 (2014).

31. D. Y. Liu and T. L. Kelly, Nat. Photon., 8, 2, 133 (2014).

32. I. Huang, K. Yong, ACS Appl. Mater. Inter., 8, 4226 (2016).

33. M. Kulbak, D. Cahen, G. Hodes, J. Phys. Chem. Lett., 6, 2452 (2015).

34. L. Qi, G. Mao, J. Ao, Appl. Surf. Sci., 254, 18, 5711 (2008). 
35. R. J. Sutton, G. E. Eperon, L. Miranda, E. L. Parrott, B. A. Kamino, J. B. Patel, M. T. Hörantner, M. B. Johnston, A. S. Haghighirad, D. T. Moore, H. J. Snaith, Adv. Energy Mater., pp. 1502458 (2016).

36. C. K. Moller, Nature, 182, 1436 (1958).

37. S. Sharma, N. Weiden, A. Weiss, Z. Phys. Chem., 175, 63 (1992).

38. A. Niemegeers and M. Burgelman, Proc. 25th IEEE Photovoltaic Spec. Conf., Washington DC, IEEE, 901 (1996).

39. S. Bansal, P. Aryal, Proc. 43rd IEEE Photovoltaic Spec. Conf., Portland, OR (2016).

40. R. E. Beal, D. J. Slotcavage, T. Leijtens, A. R. Bowring, R. A. Belisle, W. H. Nguyen, G. F. Burkhard, E. T. Hoke, M. D. McGehee, J. Phys. Chem. Lett., 7, 746 (2016).

41. E. T. Hoke, D. J. Slotcavage, E. R. Dohner, A. R. Bowring, H. I. Karunadasa, M. D. McGehee, Chem. Sci., 6, 613 (2015).

42. O. Dupré, R. Vaillon, M. A. Green, Sol. Energy Mat. Sol. Cells, 140, 92 (2015).

43. R. J. Sutton, G. E. Eperon, L. Miranda, E. S. Parrott, B. A. Kamino, J. B. Patel, M. T. Hörantner, M. B. Johnston, A. A. Haghighirad, D. T. Moore, H. J. Snaith, Adv. Energy Mat., 6, 8 (2016).

44. M. H. Futscher and B. Ehrler, ACS Energy Lett., 1, 4, 863 (2016).

45. T. Todorov, T. Gershon, O. Gunawan, Y. S. Lee. C. Sturdevant, L.-Y. Chang, S. Guha, Adv. Energy Mat., 5, 23, 1500799 (2015). 